\title{
CORPORATE SOCIAL RESPONSIBILITY: SEBUAH KENISCAYAAN STRATEGI BISNIS DI INDONESIA
}

\author{
Nila Firdausi Nuzula \\ Fakultas Ilmu Administrasi Universitas Brawijaya \\ J1. MT Haryono No. 163 Malang. Telepon: (0341) 553737, Fax (0341) 558227
}

\begin{abstract}
There is a new trend that corporation focus not only to maximize wealth for the stockholder and to pursue short term profit but also to maintain its sustainability. CSR as a global business strategy and behavior has been a need for long term corporate sustainability. CSR supports good relationship between corporate and the stakeholders. As a strategy, CSR is a must for developing social capital and for financial and long term non-financial return.
\end{abstract}

Key words: corporate social responsibility, business strategy, CSR's practice in Indonesia

Corporate Social Responsibility (CSR) sebagai sebuah konsep, merupakan turunan dari etika bisnis, suatu falsafah bahwa perusahaan, terutama yang profitoriented, diharapkan memiliki kepedulian terhadap masalah sosial yang terjadi di sekelilingnya. Sebagai suatu strategi, sejak tahun 1960an, banyak peneliti Amerika telah mengkaji frekuensi, intensitas dan bentuk aktifitas sosial kemasyarakatan yang dilakukan perusahaan bisnis. Hingga 20 tahun terakhir, CSR tidak lagi hanya berbentuk sebagai pandangan dan filosofi saja, tetapi telah menjadi suatu praktik bisnis dan panduan moral guna menghadapi masalah sosial dan lingkungan. Dalam tulisan ini, penulis bermaksud untuk menguraikan latar belakang konsep CSR, aplikasinya dalam dunia bisnis sebagai suatu strategi, dan perkembangan bentuk-bentuk aplikasinya di Indonesia saat ini. Lebih lanjut, pembahasan tentang latar belakang sejarah CSR sebagai suatu konsep, diawali dengan berbagai pemikiran tentang sejauh mana kemanfaatan suatu organisasi bisnis dalam masyarakat.

\section{EKSISTENSI PERUSAHAAN (BUSINESS) DALAM MASYARAKAT}

Sebagai suatu sistem yang 'hidup', perusahaan dikendalikan oleh para manajer bisnis yang mengkoordinasikan berbagai aktifitas pegawainya, tumbuh 
dan bergerak dalam lingkungan makro yang bersinggungan dengan sistem lainnya, baik berbentuk organisasi usaha lainnya ataupun masyarakat. Tidak dapat dipungkiri bahwa meskipun terdapat berbagai implikasi dari kehidupan yang berdampingan tersebut, namun setiap organisasi yang hidup menginginkan bentuk yang mampu memberikan posisi saling menguntungkan. Penerimaan masyarakat atas keberadaannya seperti itu akan mengarahkan pada sustainability yang sesuai dengan prinsip going concern suatu organisasi bisnis.

Dalam masyarakat secara luas, fungsi efektif dan efisien suatu organisasi bisnis dapat dilihat dari tiga tujuan (Luthans et. al, 1990) yaitu: pertama, memberikan kontribusi ekonomi makro secara signifikan, berupa adanya nilai tambah (value added) atau gaji, terutama jika diukur dengan menggunakan Gross National Product (GNP) sebagai indikator aktifitas ekonomi suatu negara. Para pengusaha ini berpotensi untuk dapat meningkatkan kesejahteraan masyarakat umum melalui penyediaan lapangan pekerjaan dan kompensasi pada para pegawainya, serta kesejahteraan para pemegang saham.

Gambar 1

Manfaat Perusahaan Bisnis

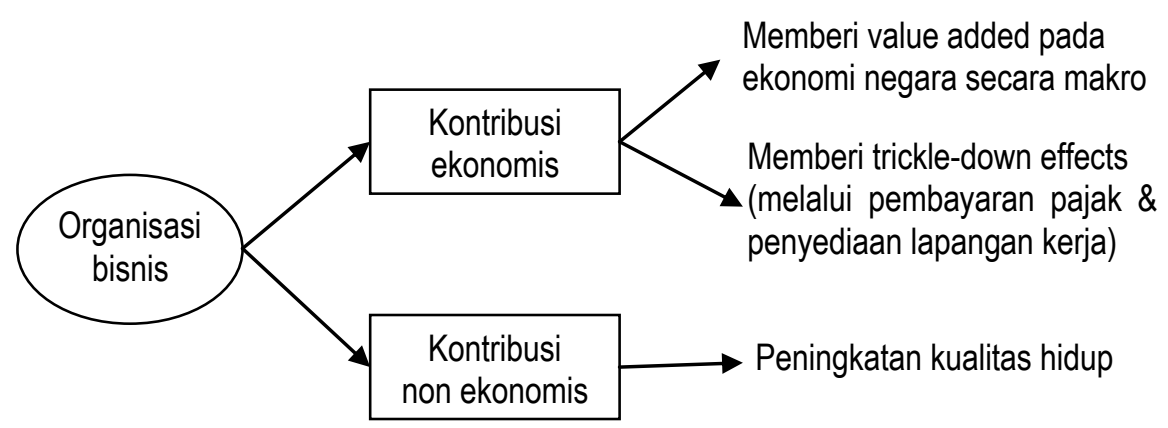

Sumber: Luthans, Fred, Hodgetgs, Richard M. and Thompson, Kenneth R. 1990 (6 th $^{\text {th }}$.) Social Issues in Business: Strategic and Public Policy Perspectives, New York: McMillan Publishing Company.

Kedua, eksistensi perusahaan bisnis memiliki manfaat trickle-down effect., yaitu sebagai penyedia dana bagi pembiayaan program-program kesejahteraan sosial melalui pembayaran pajak yang mereka lakukan. Dalam hal ini pembayaran pajak diartikan sebagai kompensasi perusahaan atas hak privilege yang telah diberikan pemerintah bagi mereka untuk beroperasi pada daerah tertentu. Pada konteks ini telah terjadi sharing of profits antara pemerintah dan organisasi bisnis. 
Bentuk lain trickle-down effect perusahaan bisnis adalah berhubungan dengan peningkatan kemampuan ekonomi suatu negara. Melalui aktifitas produksi dan distribusi atas barang-barang yang dibutuhkan masyarakat, keberadaan organisasi bisnis dapat menggerakkan roda perekonomian dengan menyediakan lapangan pekerjaan, yang kemudian berdampak pada peningkatan pendapatan pegawai/masyarakat luas. Dengan demikian, tugas pemerintah untuk menanggulangi pengangguran dan kemiskinan menjadi lebih ringan.

Ketiga, perusahaan bisnis mendorong peningkatan kualitas hidup individual masyarakat dengan makin tingginya perhatian terhadap persamaan hak untuk kaum minoritas dan perempuan dan proteksi atas eksploitasi yang berlebihan atas lingkungan hidup. Dengan demikian, dapat disimpulkan bahwa perusahaan bisnis juga memiliki manfaat non ekonomi, selain manfaat ekonomi seperti dalam bentuk pertama dan kedua sebelumnya.

Selain hidup berdampingan dengan masyarakat, keberadaan organisasi bisnis juga ditentukan oleh pemerintah, yang dalam hal ini juga memiliki pengaruh yang signifikan dalam sendi kehidupan masyarakat. Ketiganya saling berinteraksi dan bergantung. Aktifitas bisnis berdampak pada masyarakat, sementara kebijakan pemerintah juga memiliki dampak langsung atau tidak langsung pada perusahaan. Manajer perusahaan bisnis perlu memahami hubungan interdependensi antara ketiganya guna merumuskan kebijakan bisnis yang efektif. Lebih lanjut, hubungan ketiganya dapat dipilah dalam tiga level seperti pada tabel di bawah ini:

Tabel 1

3 Level Hubungan antara Bisnis, Pemerintah dan Masyarakat

\begin{tabular}{|l|l|l|l|}
\hline \multicolumn{1}{|c|}{ Level } & \multicolumn{1}{|c|}{ Business } & \multicolumn{1}{c|}{ Society } & \multicolumn{1}{c|}{ Government } \\
\hline Konseptual & Ekonomi & Budaya & Politik \\
\hline Intermediate & Industri & Stakeholder & $\begin{array}{l}\text { Pemerintah } \\
\text { (nasional, asing, } \\
\text { lokal) }\end{array}$ \\
\hline $\begin{array}{l}\text { Manajemen } \\
\text { terapan }\end{array}$ & $\begin{array}{l}\text { Perusahaan } \\
\mathrm{X}\end{array}$ & $\begin{array}{l}\text { Stakeholder } \\
\text { primer dan } \\
\text { sekunder }\end{array}$ & Aktor pemerintah \\
\hline
\end{tabular}

Sumber: Post, James E., Lawrence, Anne T., and Weber, James. 2002 (10 th ed.) Business and Society: Corporate Strategy, Public Policy, Ethics, New York: McGraw-Hill Companies. 
Tingkatan konseptual merupakan gambaran hubungan yang paling luas dari perspektif hubungan sosial yang menekankan hubungan sistemik antara aktifitas ekonomi negara, kehidupan politis dan unsur budaya. Sementara itu, di level intermediate, hubungan terjadi ada pada tingkat pelaku yaitu pada tiap kelompok industri sebagai pelaku bisnis, institusi pemerintah di berbagai level, serta stakeholder. Dan di level manajemen praktis, relasi yang terjadi adalah pada tingkat antar perusahaan, stakeholder dan aktor pemerintah.

Sebenarnya konsep hubungan Business-Government-Society (BGS) telah banyak dipelajari sejak pertengahan abad 20an. Oleh karenanya, terdapat 5 model hubungan interdependensi BGS yang telah berkembang, yaitu Dominance Model, Market Capitalism Model, Business Ecology Model, Dominant Force Model dan Stakeholder Model (lihat Steiner and Steiner, 2000). Beberapa model diantaranya memandang organisasi bisnis sebagai sistem terbuka yang dapat dipengaruhi oleh berbagai faktor eksternal, sementara model yang lainnya berlandaskan pada konsep bahwa organisasi bisnis bersifat independen dan mampu mempengaruhi institusi lain di luar manajemennya. Institusi lain di luar organisasi bisnis ini memiliki beragam bentuk dan fungsi, sehingga dalam mengkaji besarnya pengaruh mereka terhadap eksistensi organisasi bisnis, dalam Stakeholder Concept, Post et.al (2002) membaginya dalam primary stakeholder dan secondary stakeholders.

Secara riil, keberadaan perusahaan bisnis tidak terlepas dari hubungan timbal baliknya dengan stakeholdernya. Perusahaan memerlukan interrelasi yang baik dengan para suppliernya, sebagaimana hubungan baiknya dengan lembaga lain di sektor hilir, seperti distributor dan pelanggan. Di sisi lain, perusahaan juga memiliki kaitan istimewa dengan para pekerja, pemerintah setempat dan lingkungan fisik dimana perusahaan tersebut berdiri dan beroperasi. Gambaran kemanfaatan di atas menjadikan perusahaan memiliki hubungan unik dengan masyarakat. Singkatnya, masyarakat (society) bertindak sebagai input sekaligus output perusahaan. Mengingat kedua posisi tersebut merupakan penopang kemampuan survival suatu organisasi, maka tujuan perusahaan bisnis pada setiap level akan diarahkan untuk menjaga hubungan baik dengan masyarakat untuk kepentingan kelangsungan hidup perusahaan. 


\section{PERDEBATAN TENTANG CORPORATE SOCIAL RESPONSIBILITY (CSR)}

Konsep CSR telah menjadi obyek perdebatan sejak awal dikenalkannya pada akhir millennium lalu. Perdebatan tersebut begitu serunya sehingga melibatkan banyak akademisi. Newman Peery, Jr. (1995) membahas secara menarik perdebatan tersebut sebagaimana dijelaskan dalam paparan berikut. Peery memulai pembahasannya dengan pendapat Milton Friedman yang menyebutkan bahwa CSR akan mengurangi kebebasan masyarakat. Ia mengungkapkan bahwa para manajer perusahaan diangkat oleh para pemegang saham untuk meningkatkan kinerja perusahaan sehingga memberikan tambahan kekayaan bagi para pemegang saham. Sebaiknya para manajer dapat meningkatkan kontribusinya kepada masyarakat dengan menggunakan sumber daya pribadinya. Jika para manajer menggunakan sumber daya perusahaan untuk menyumbang masyarakat dengan tanpa memberikan pengaruh nyata terhadap kinerja ekonomi perusahaan maka si manajer dapat dianggap telah memalak para pemegang saham dan menyalahgunakan sumberdaya tanpa akuntabilitas yang jelas. Para manajer yang terlibat aktif dalam CSR dianggap telah mengambil alih peran pemerintah, menyalahgunakan kekayaan pihak lain, dan mengurangi kebebasan masyarakat.

Sementara itu penentang CSR lainnya, yakni Theodore Levitt mengungkapkan bahwa CSR akan membawa dampak buruk bagi bisnis dan jelek pula bagi masyarakat. Levitt memandang bahwa masyarakat telah terbagi dalam berbagai kelompok seperti kelompok social, ekonomi, dan politik. Setiap kelompok memiliki fungsi masing-masing. Misalnya kelompok buruh bertanggung jawab untuk memperjuangkan kepentingan kaum pekerja, sementara pemerintah berkewajiban untuk menyelenggarakan kesejahteraan umum, dan pada saat yang sama bisnis bertanggung jawab untuk memaksimalkan laba dengan memelihara persaingan usaha. Kebebasan individu justeru terpelihara dengan baik apabila terdapat kemandirian dalam setiap kelompok tersebut untuk memperjuangkan fungsinya masing-masing. Levitt memandang bahwa kehadiran CSR justeru akan mengurangi kemampuan persaingan usaha sehingga justeru akan melemahkan kondisi masyarakat secara keseluruhan. 
Argumen lain yang menentang CSR lebih bersifat filosofis ketika mengaitkannya dengan sifat dari seorang "moral agent". Dapatkah sebuah perusahaan bertindak seperti manusia yang bermoral? Gibson telah mendesak bahwa kita tak dapat memberikan hukuman kepada sebuah perusahaan sebagai sebuah perusahaan. Seseorang yang bekerja di sebuah perusahaan dapat dipersalahkan dan dihukum atas kekeliruannya namun bukan perusahaan itu sendiri. Sebuah perusahaan tak dapat dipenjara atau dihukum mati karena yang bisa demikian hanyalah seorang manusia. Senada dengan hal tersebut, Velasquez mengatakan bahwa perusahaan tak dapat bertindak secara moral yang hanya dapat dilakukan oleh manusia. Organisasi tak dapat diberi maaf atau dianjurkan masuk neraka atau surga seperti dalam pandangan agama. Dengan demikian, organisasi tak dapat dimintai pertanggung-jawaban moral, karena perusahaan bukanlah "moral agent" dan tak dapat dimintai pertanggung-jawaban moral atas tindakannya. Jika tak dapat bertanggung-jawab secara moral maka mengapa harus ada tanggung jawab social perusahaan (CSR)? Perusahaan hanyalah dapat bertanggung jawab secara legal sehingga menjadi subyek hukum dan dapat dimajukan ke meja pengadilan. Perusahaan tidak memiliki pertanggung-jawaban moral karena pertanggung jawaban moral hanya terletak pada individu (termasuk para manajer secara pribadi). Secara jelas hal tersebut digambarkan sebagai berikut:

\section{Gambar 2 Argumen Penentang CSR}

\section{ARGUMEN PENENTANG CSR}

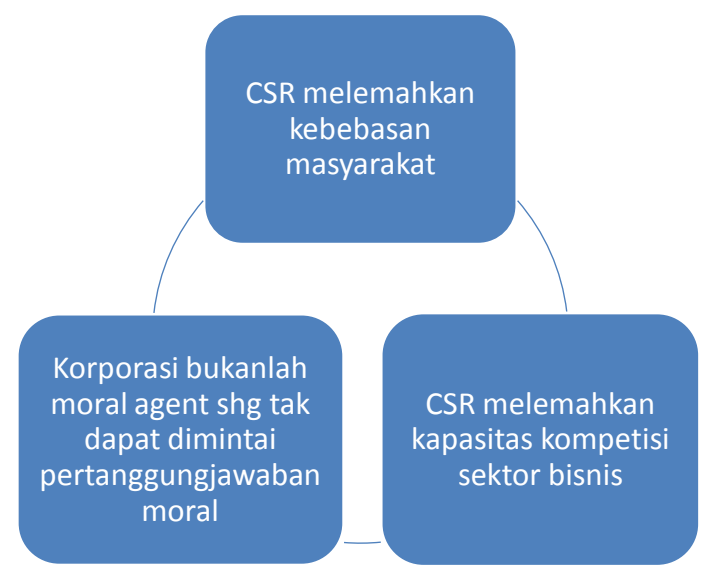


Selanjutnya Peery, Jr. (1995) mengungkapkan pula argumen balasan yang mendukung CSR. Pertama, korporasi/perusahaan dapat disebut memiliki kesadaran sehingga dapat dimintai pertanggung jawaban moral terhadap berbagai akibat dari tindakan korporasi tersebut. Kedua, perusahaan sebenarnya muncul sebagai akibat dari sebab yang berupa kontrak sosial. Ketiga, kontrak social senantiasa berubah seiring dengan perubahan ekspektasi masyarakat. Keempat, bisnis memiliki kapabilitas dan sumberdaya untuk melakuka perbaikan masyarakat sehingga para manajer wajib untuk menjalankan CSR. Kelima, penyelesaian masalah-masalah social bergantung pada semua pihak tanpa kecuali, termasuk bisnis. Keenam, CSR sejalan dengan kepentingan ekonomi jangka panjang dari setiap bisnis.

Organisasi merupakan sistem sosial dimana para angotanya telah berbagi nilai dan budaya organisasi. Sistem nilai bersama inilah yang membentuk kesadaran korporasi. Pengetahuan yang disebarkan dalam berbagai unit atau jenjang keorganisasian telah mewarnai nilai-nilai pribadi. Dengan demikian, perusahaan dapat disebut telah memiliki kesadaran dan dapat dimintai pertanggung-jawaban moral (Monks \& Minow, 2004). Korporasi harus bertanggung jawab secara social atas perilaku organisasinya dan harus dimintai pertanggung-jawaban atas akibat dari setiap tindakan perusahaan.

Korporasi pada dasarnya terbentuk karena dikukuhkan oleh pemerintah, yang berbentuk sebuah kontrak sebagai dasar eksistensinya. Dalam perikatan tersebut, masyarakat membawa korporasi secara legal menjadi ada dan dengan demikian pemerintah mempunyai kekuasaan untuk membatasi perilaku bisnisnya. Pada saat yang sama, masyarakat juga mempunyai hak untuk mengubah ekspektasinya terhadap bisnis sebagai instrument masyarakat. Sebagaimana sektor pemerintah dan masyarakat itu sendiri, dalam konsep governance bisnis juga merupakan salah satu aktor penting dalam pemenuhan kebutuhan masyarakat.

Bisnis yang dikendalikan oleh perusahaan pada dasarnya bergantung pada kekuatan pasar yang berarti kekuatan yang ada dalam penawaran (supply). Penawaran lebih diwarnai oleh nilai-nilai masyarakat kebutuhan social sehingga ideology pasar dan liberal yang menekankan pada kepemilikan pribadi (private property) serta hak dan kewajiban perusahaan. Dengan demikian sebenarnya 
bisnis tidak tunduk pada bisnis itu sendiri tetapi dikendalikan oleh kekuatan masyarakat dan diatur oleh pemerintah. Karena hubungan yang begitu lekat dan saling bergantung antara bisnis, masyarakat dan pemerintah maka wajar jika CSR wajib dijalankan oleh korporasi sebagai bagian dari tanggung jawab moralnya.

Selain itu, banyak keputusan dan kegiatan bisnis yang memiliki pengaruh terhadap masyarakat setempat, lingkungan ekologisnya, dan beragam aspek lainnya dalam masyarakat. Pengaruh tersebut berada di luar arena pasar dan dengan demikian menjadi kepentingan masyarakat yang lebih luas meskipun tidak terkait langsung dengan proses pertukaran-pasar. Misalnya jika korporasi tidak mengendalikan polusi yang dihasilkan dari operasi fasilitasnya maka masyarakat luaslah yang akan menanggung akibatnya. Dengan dalih inilah maka CSR mengharuskan setiap bisnis untuk secara serius mempertimbangkan dampak dari kegiatan bisnisnya bagi masyarakat (lihat pula Monks \& Minow, 2004).

\author{
Gambar 3 \\ Argumen Pendukung CSR
}

\title{
ARGUMEN PENDUKUNG CSR
}

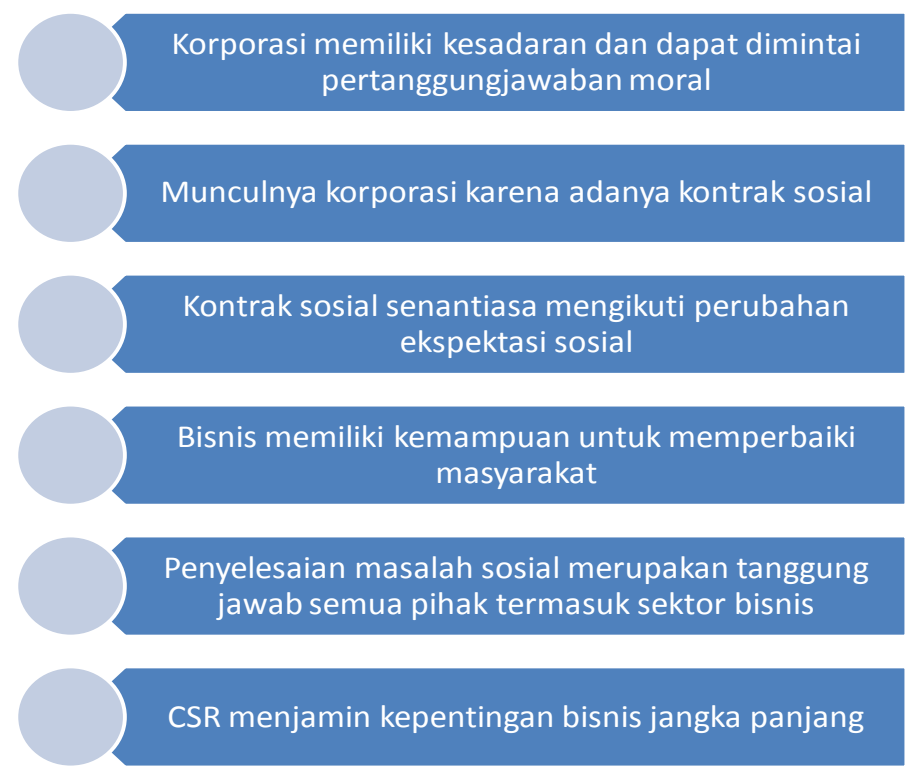


Dalam dimensi yang berbeda, Keith Davis (sebagaimana dikutip oleh Peery, 1995) menganjurkan penerapan CSR sebagai sumbangsih korporasi terhadap persoalan yang dihadapi oleh masyarakat. Pengetahuan, kemampuan, dan sumber daya yang dimiliki korporasi dapat digunakan untuk menyelesaikan problema social. Ada harapan di masyarakat bahwa persoalan sosial tidak hanya menggunakan kekuatan sosial karena ada kekuatan lain yang diharapkan dapat digunakan secara bersama untuk menyelesaikan persoalan tersebut. Karena korporasi tidak hidup sendirian dalam ruang hampa namun justru berada dalam ruang sosial maka wajarlah apabila bisnis turut serta menyelesaikan persoalan masyarakat. Hal ini berarti mendukung dan memperbaiki ruang sosial tempat bisnis itu sendiri hidup. Sehatnya ruang sosial sama dengan memperpanjang umur korporasi itu sendiri.

Jika para penentang CSR menyajikan argumen yang pada intinya didasarkan pada dampak CSR yang mengurangi pencapaian laba maksimum maka sebenarnya argument tersebut didasarkan pada kalkulasi laba jangka pendek yang menyebabkan berkurangnya deviden para pemegang saham dan berkurangnya sumber daya korporasi. Kelangsungan hidup korporasi sebenarnya didasarkan pada penerapan strategi yang tepat dalam menghitung tantangan dan peluang serta kekuatan dan kelemahan dalam dimensi waktu yang tepat. Dalam konteks ini pertimbangan jangka pendek ini selalu dikontrol dengan pertimbangan jangka panjang. Para pendukung CSR menilai bahwa penerapan CSR memberi manfaat jangka panjang bagi kepentingan bisnis itu sendiri. Keuntungan jangka panjang dapa diperoleh dengan mematuhi regulasi yang berlaku serta mempertimbangkan dampak non pasar atas keputusankeputusan bisnis yang diambil. Para pendukung CSR selalu mengedepankan untuk menangguk manfaat jangka panjang ini sepanjang tidak membahayakan laba jangka pendek perusahaan.

Perdebatan tentang CSR ini telah berlangsung lama, namun pemetaan yan dilakukan oleh Archie B. Carroll pada tahun 1991 (dalam Peery, 1995) menunjukkan bahwa perdebatan tersebut berada pada spectrum yang cukup luas. Carroll menyajikan piramida CSR yang tidak saja menjelaskan empat aspek perdebatan (yakni tanggung jawab ekonomi, legal, etik, dan filantropis) namun juga susunan hubungan antar empat aspek tersebut dalam pondasi sosial yang 
lebih luas. Kinerja ekonomi merupakan pondasi utama CSR. Sebagai instrumen utama dalam ruang lingkup ekonomi masyarakat maka tugas utama bisnis adalah menyediakan barang dan jasa yang dibutuhkan oleh masyarakat melalui mekanisme pasar. Sistem pasar memiliki ciri saling bergantung antara penjual dan pembeli, antara penawaran dan permintaan. Bagi pembeli, pemenuhan kebutuhan dan keinginan mereka merupakan hal yang utama dalam keberlanjutan system pasar. Bagi penjual, keuntungan yang diperoleh merupakan hal utama kehadiran mereka dalam system pasar. Seringkali pencapaian laba sebesar-besarnya dalam jangka pendek diikuti dengan tindakan-tindakan tak bertanggung-jawab dalam system kehidupan yang lebih luas. Oleh karena itu, pencapaian laba tidak dihitung secara maksimum namun optimum sehingga perlu mempertimbangkan keberlanjutan bisnis dalam jangka panjang. Dalam konteks inilah CSR diperlukan untuk menjamin kelangsungan bisnis di masa depan. Dengan pondasi ini maka seharusnya pula CSR tetap dijalankan dengan tidak mengorbankan pencapaian laba sebagai faktor utama kehadiran perusahaan dalam sistem pasar.

\section{Gambar 4 \\ Piramida CSR}

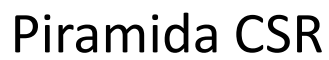

Archie B. Carrol (1991)

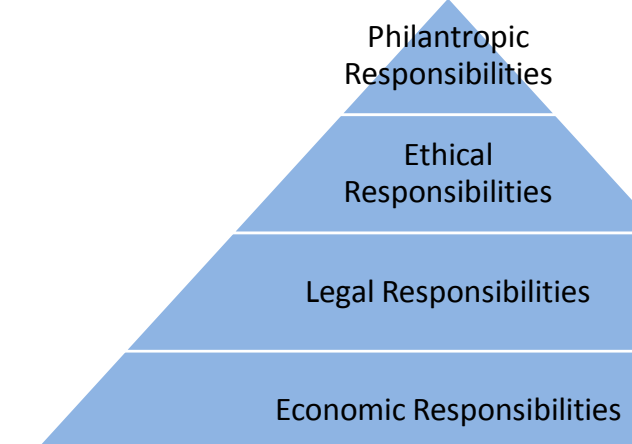

Setelah tanggung jawab ekonomi terpenuhi sebagai pondasi, umumnya perdebatan tentang CSR berlanjut pada aspek legal. Setiap korporasi pada dasarnya adalah badan hukum yang disahkan oleh pemerintah. Regulasi tentang pembentukan badan hukum dan beroperasinya badan hukum tersebut 
sebenarnya berasal dari tatanan yang ditegakkan oleh masyarakat. Kepatuhan korporasi terhadap norma-norma dan aturan main baik tentang bisnis dan hubungan bisnis serta hubungan dengan system social yang lebih luas merupakan kewajiban yang melekat dalam setiap badan hukum (Monks \& Minow, 2004). Regulasi pada dasarnya merupakan hasil dari proses kebijakan publik yang diterapkan dalam masyarakat yang mencerminkan kepentingan yang hidup dalam masyarakat. Jika regulasi menghendaki produksi barang yang memenuhi standar keselamatan dan keamanan, ramah lingkungan, serta adanya pelaporan keuangan seperti yang telah diatur maka menjadi kewajiban bisnis untuk memenuhinya. Perdebatan apakah korporasi merupakan badan hukum yang merupakan subyek hukum tampaknya mengecil karena pada dasarnya baik pihak yang pro dan kontra terhadap CSR mengakui bahwa korporasi merupakan badan hukum. Perbedaan terbesar terletak pada pandangan apakah korporasi tunduk pada hokum atau lebih mengedepankan pertimbangan ekonomi semata. Sebagai badan hukum yang berada dalam perikatan sosial maka sebenarnya korporasi tidak memiliki pilihan lain selain kepatuhan kepada norma hukum dan regulasi yang berlaku.

Perdebatan selanjutnya masuk dalam ranah etika ketika para penentang CSR menyebutkan bahwa korporasi bukanlah "moral agent" karena yang berurusan dengan moral adalah orang-orang dalam organisasi. Para manajer, karyawan, dan pemilik merupakan orang-orang dalam organisasi. Merekalah yang secara pribadi bertanggung-jawab dalam hubungan sosial sehingga tidak dapat menggunakan sumberdaya korporasi bagi kepentingan sosial. Tentu para pendukung CSR mengatakan bahwa CSR juga merupakan "moral agent" dan harus mempertimbangkan etika dalam mengambil keputusan organisasional. Tanggung jawab etis ini penting dalam pandangan teori utilitarian, teori hak asasi, dan teori keadilan karena setiap korporasi memiliki hak dan tanggung jawab sosialnya masing-masing. Setiap korporasi harus mempertimbangkan dampak dari kegiatan dan keputusan korporasi bagi masyarakat baik yang berupa dampak langsung maupun tak langsung, baik dampak jangka pendek maupun jangka panjang (Weihrich \& Koontz, 1993).

Setelah tanggung jawab etis, lalu perdebatan berkembang pada ranah tanggung jawab filantropis. Tanggung jawab ini berkenaan dengan apakah 
keputusan dan tindakan korporasi telah benar-benar merupakan pemenuhan dari ekspektasi masyarakat. Para penentang CSR berpendapat bahwa tanggung jawab filantropis telah secara langsung merupakan trade-off dalam kinerja ekonomi perusahaan. Kegiatan filantropis memberikan maslahat langsung kepada masyarakat namun secara langsung pula merupakan biaya bagi korporasi (lihat Henderson, 1979). Semakin besar kemaslahatan diberikan maka semakin besar biaya bagi korporasi sementara kemanfaatan ekonomis langsungnya tidak ada bagi perusahaan. Kegiatan filantropis seperti pemberian beasiswa, donasi sosial, pendanaan kegiatan amal, sponsorship bagi kegiatan kesenian dan kebudayaan merupakan aktivitas yang memperbesar biaya namun tidak menghasilkan pendapatan bagi korporasi. Ini tentu mengurangi laba jangka pendek korporasi. Meski dari segi ekonomi tanggung jawab filantropis ini bersifat kontroversial namun bagi para pendukung CSR tanggung jawab ini akan membentuk citra sebagai good corporate citizen (lihat Rubenstein, 2004). Citra baik yang diperoleh perusahaan akan meningkatkan dukungan masyarakat terhadap keberadaan perusahaan tersebut di lingkungan sosialnya. Hal ini tidak saja menguntungkan bagi perusahaan tetapi juga bagi orang-orang dalam perusahaan. Citra baik perusahaan akan menyebabkan keuntungan tersendiri yang bersifat tak langsung bagi pencapaian laba namun bersifat langsung bagi eksistensi sosial perusahaan.

\section{CORPORATE SOCIAL RESPONSIBILITY (CSR) SEBAGAI SUATU STRATEGI PERUSAHAAN}

Seperti yang telah diuraikan sebelumnya bahwa sebagai organisasi yang bergantung pada masyarakat - mengingat posisi masyarakat sebagai penyedia input dan penampung output perusahaan - maka dapat dikatakan bahwa kemampuan hidup organisasi bisnis dapat diprediksi dari kualitas hidup masyarakat di sekitarnya. Untuk itu, perusahaan dipandang perlu mengembangkan strategi guna memastikan bahwa masyarakat memiliki kemampuan dan kemauan dalam menyediakan iklim dan kondisi yang dibutuhkan perusahaan untuk tetap survive. Dalam hal ini, upaya perusahaan untuk memelihara kondisi masyarakat seperti hal di atas, menurut Luthans et. al 
(1990), dapat disebut sebagai bentuk tanggung jawab perusahaan bisnis (Corporate Social Responsibilities atau CSR).

Dengan konsep CSR seperti yang telah dikemukakan sebelumnya, sebenarnya tidak ada kesepakatan diantara para pakar tentang definisi, ruang lingkup dan tujuan implementasi CSR. Oleh karenanya, secara umum CSR didefinisikan sebagai aktifitas sosial yang dilakukan oleh perusahaan di luar kepentingan ekonomi perusahaan dan ketentuan hukum.

The World Business Council on Sustainable Development pada 1998 mendefinisikan CSR sebagai: "the continuing commitment by business to behave ethically and contribute to economic development while improving the quality of life of the workforce and their families as well as of the local community and society at large." Namun kemudian definisi tersebut diperbarui pada tahun 2002 yaitu: "the commitment of business to contribute to sustainable economic development, working with employees, their families, the local community and society at large to improve their quality of life" (Blowfield and Frynas, 2005).

Dari definisi tersebut, tampak bahwa konteks CSR meliputi seluruh dampak aktifitas perusahaan pada masyarakat atau dengan kata lain stakeholder, yaitu mencakup kelompok shareholder, customer, supplier, employee dan community atau masyarakat umum, baik lokal ataupun global. Dengan demikian, key issue yang ada di dalam pendekatan ini bervariasi, utamanya terkait dengan: hak asasi manusia, kondisi tenaga kerja, dampak lingkungan dari produk, proses produksi dan distribusi, dampak operasi pada masyarakat lokal, serta dampak kesehatan produk atau jasa pada pelanggan. Selain itu, ruang lingkup praktik CSR ini juga mencakup lingkungan hidup (natural resources).

Corporate social responsibility (CSR) menjadikan perusahaan bisnis tertantang untuk lebih accountable atas setiap konsekuensi dari setiap aktifitas perusahaan yang mempengaruhi stakeholder mereka. Perusahaan yang hanya mengejar profit semata nampaknya bukan lagi menjadi 'trend' strategi bisnis saat ini. Perusahaan dinyatakan sukses jika tim manajemen yang mampu memenuhi berbagai tanggung jawab (ekonomis, legal dan sosial) serta mampu mengembangkan strategi sedemikian rupa sehingga seluruh tanggung jawab dapat terpenuhi. 
Tidak dipungkiri bahwa upaya tersebut bukanlah hal yang mudah. Dibutuhkan kepemimpinan dari top management yang memiliki visi yang kuat sebab manajer ini harus memiliki kemampuan untuk mengenali dan mengantisipasi setiap perubahan sosial yang akan berdampak pada operasi bisnis. Selain itu, manajer ini harus mampu menyesuaikan diri dengan berbagai peraturan pemerintah, karena pemerintah umumnya bertindak sebagai aktor yang lebih terbuka terhadap kebutuhan stakeholder. Perusahaan seperti ini disebut sebagai enlightened self-interest (Post et. al, 2002), yaitu perusahaan yang memiliki social awareness tanpa meninggalkan kepentingan ekonomisnya.

Sebagai strategi baru, beberapa manajer yang cenderung konservatif tentunya akan mempertanyakan beberapa hal seperti: “Dengan bertindak lebih memperhatikan masalah sosial, apakah laba perusahaan akan berkurang? Bagaimana penerimaan profit mereka, apakah mereka mampu mencapai laba yang lebih tinggi dibandingkan perusahaan yang cenderung mengabaikan masalah sosial?" Banyak penelitian yang mengkaji hubungan antara social performance dengan financial performance suatu perusahaan. Meskipun hasil yang ditemukan beragam, akan tetapi ada kecenderungan bahwa perusahaan yang menunjukkan perhatian pada masalah sosial juga akan memiliki kinerja finansial yang baik. Terutama di perusahaan-perusahaan di Amerika, ada asosiasi positif antara kinerja sosial dan finansial mereka.

\section{APLIKASI CORPORATE SOCIAL RESPONSIBILITY (CSR) DI INDONESIA}

Tanggung jawab sosial bukan lagi menjadi wacana di negara-negara maju. Sebagai nilai budaya organisasi, konsep tanggung jawab sosial telah mendunia dan diadopsi oleh perusahaan-perusahaan di berbagai negara sehingga telah menjadi praktik bisnis global terutama terkait dengan upaya meramu hubungan yang baik antara pelaku bisnis dengan masyarakat. Dengan latar belakang budaya di setiap negara yang berbeda, menjadikan konsep CSR diaplikasikan dalam berbagai bentuk yang berbeda di setiap negara. Sebagai contoh, perusahaan-perusahaan Jepang meyakini bahwa jika mereka menolong masyarakat lokal yang secara fisik berada dekat dan berhubungan dengan operasi bisnis mereka, itu bermakna bahwa mereka sama halnya dengan menolong diri mereka sendiri. 
Di Indonesia, sejak tahun 1990an perusahaan-perusahaan di Indonesia diketahui telah melakukan berbagai aktifitas sebagai bentuk tanggung jawab perusahaan pada masalah sosial dan lingkungan. Berdasarkan penelitian Nuzula (2007) terhadap laporan tahunan perusahaan (annual report) tahun 1995-1999 yang dikeluarkan perusahaan yang listing pada Bursa Efek Indonesia diketahui bahwa aktifitas tersebut dapat dikategorikan sebagai berikut.

\section{Gambar 5}

Ruang lingkup Penerapan CSR di Indonesia

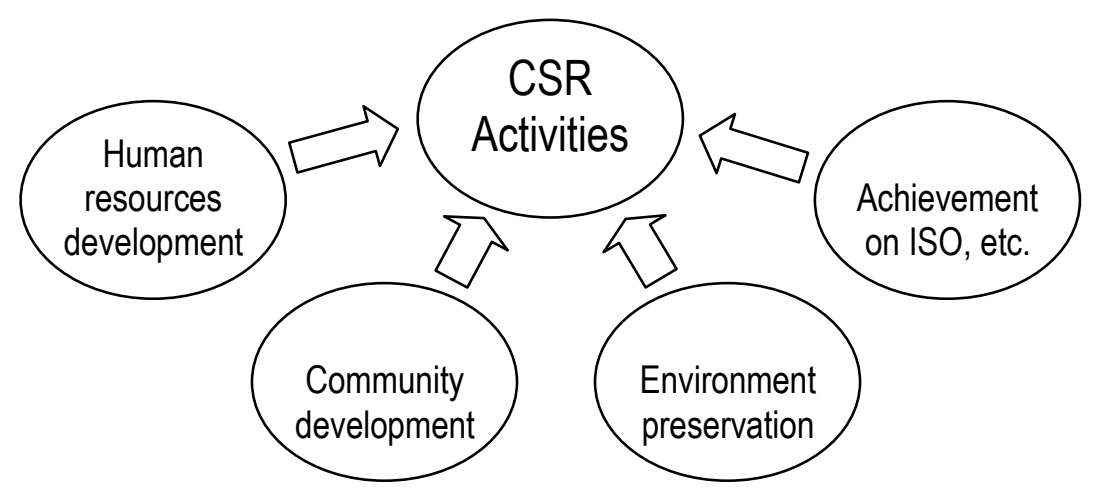

Sumber: Nuzula, N. F. 2007. Corporate Social Disclosure (CSD): Suatu Pengungkapan Informasi tentang Corporate Social Responsibility (CSR). Laporan penelitian tidak dipublikasikan, Fakultas Ilmu Administrasi Univ. Brawijaya.

Perusahaan di Indonesia sejak 1990an telah aktifitas mengembangkan potensi sumber daya manusia sebagai human capital perusahaan diantaranya berbentuk: pengelolaan karir (pelatihan dan pengembangan SDM), peningkatan kesejahteraan (remunerasi, penyesuaian gaji terhadap upah minimum dan Employee Stock Option Programme atau ESOP), asuransi Jamsostek, hubungan baik dengan serikat pekerja, serta pelatihan Kesehatan \& Keselamatan Kerja.

Di bidang community development yang ditujukan pada masyarakat lokal di sekitar perusahaan, aktifitas yang dilakukan berada di bidang keagamaan, pendidikan dan kebudayaan, sponsor kegiatan olah raga, serta social charity seperti pemberian pinjaman modal kerja pada UMKM, bantuan korban bencana. Sementara itu dalam hal lingkungan hidup, perusahaan berpartisipasi pada upaya pelestarian lingkungan dan penelitian pengelolaan limbah. Terakhir, telah banyak pula perusahaan di Indonesia yang telah mengoperasikan berbagai standar internasional tentang pengelolaan operasi bisnis seperti ISO 14000 serta pencapaian value added dalam hal penggunaan teknologi atau proses. 


\section{Gambar 6 \\ Berbagai Strategi Implementasi CSR di Indonesia}

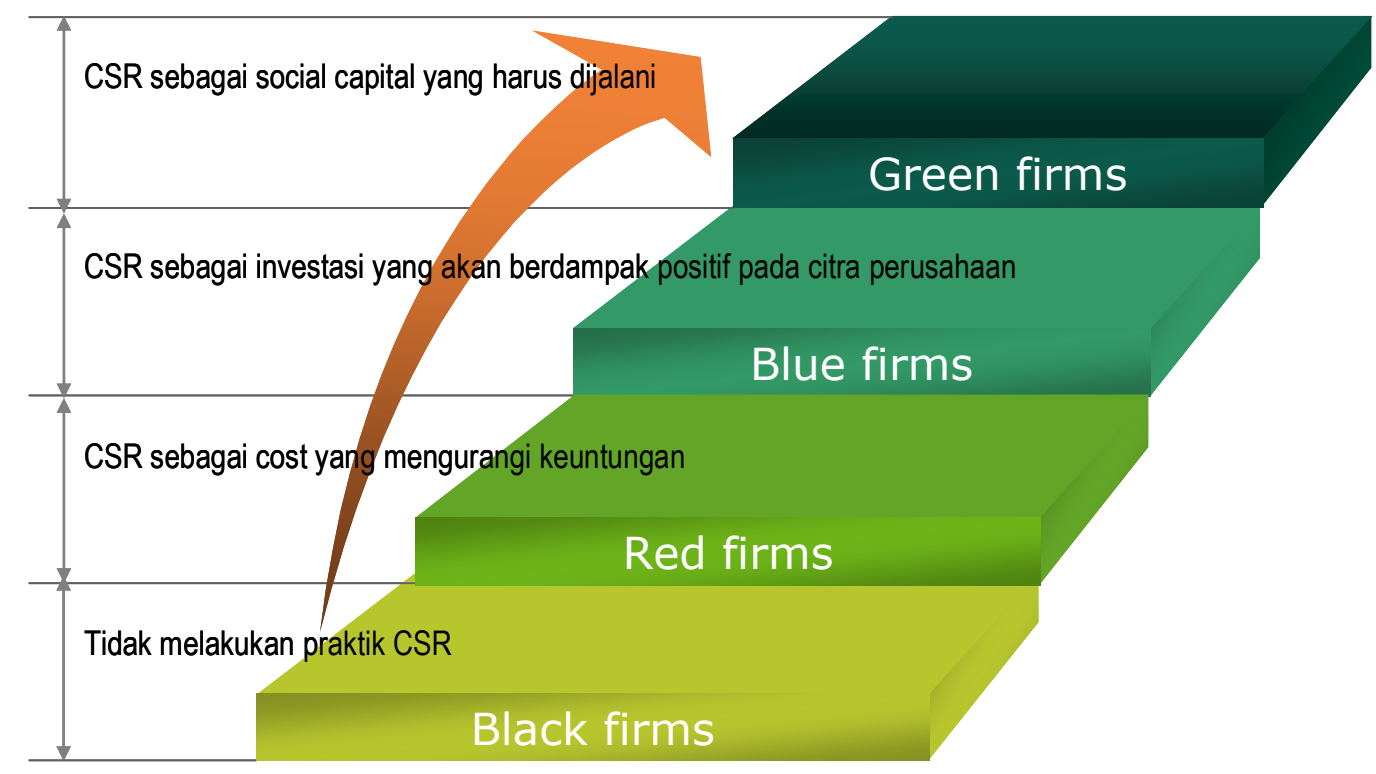

Sumber: Fajar, R. 2005. Spektrum Pelaku CSR. Majalah SWA Edisi Mei 2005.

Gambar di atas menunjukkan kategori perilaku kalangan bisnis dalam mengimplementasikan konsep CSR dalam empat golongan, yaitu berturut-turut kelompok perusahaan hitam sebagai kelompok yang sama sekali tidak mempertimbangkan CSR dalam aktifitas bisnisnya, kelompok merah sebagai kelompok perusahaan yang mulai melaksanakan praktik CSR tetapi menganggap CSR sebagai biaya yang mengurangi profit. Kelompok ketiga adalah kelompok biru yang menganggap praktik CSR sebagai investasi dan berdampak pada perolehan return bagi perusahaan. Dan terakhir, kelompok hijau yang melaksanakan praktik CSR sebagai keharusan dan kebutuhan, serta menjadikan CSR sebagai modal sosial.

\section{KESIMPULAN}

Sebagai suatu konsep, Corporate Social Responsibility (CSR) dipandang sebagai strategi penting karena pada dasarnya aktifitas bisnis merupakan kontrak sosial antara pelaku bisnis dengan masyarakat, sehingga dalam wajar jika demi menjaga sustainability-nya perusahaan memberikan timbal balik berupa perhatian terhadap masalah sosial kemasyarakatan, disamping memenuhi tanggung jawab ekonomi berupa mengoptimumkan kesejahteraan para pemegang saham. 
Di Indonesia, upaya implementasi CSR telah dilakukan terutama oleh perusahaan besar yang telah go public meskipun aktifitas tersebut masih beragam. Secara umum kegiatan tersebut berada pada lingkup pengembangan sumber daya manusia (SDM), community development, upaya pelestarian lingkungan hidup, serta implementasi standar internasional dalam operasi bisnis. Berdasarkan intensitas aktifitas praktik CSR, perusahaan di Indonesia dapat dikategorikan dalam perusahaan hitam yang tidak melakukan praktik CSR hingga perusahaan hijau yang menganggap CSR sebagai kebutuhan dan modal sosial.

\section{DAFTAR PUSTAKA}

Blowfield, Michael and Frynas, Jedrzej G. 2005. Setting New Agendas: Critical Perspectives on Corporate Social Responsibility in The Developing World. International Affairs Vol. 81, No. 3, pp. 499-513

Fajar, Rudi. 2005. Spektrum Pelaku CSR. Majalah SWA Edisi Mei 2005.

Henderson, B. C. 1979. Henderson on Corporate Strategy. Cambridge: Abt Books.

Luthans, Fred, Hodgetgs, Richard M. and Thompson, Kenneth R. 1990 (6 $6^{\text {th }}$ ed.). Social Issues in Business: Strategic and Public Policy Perspectives, New York: McMillan Publishing Company.

Monks, R. A. G. \& Minow, N. 2004 (3 ${ }^{\text {rd }}$ ed.). Corporate governance. Oxford: Blackwell Publishing, Ltd.

Nuzula, Nila F. 2007. Corporate Social Disclosure (CSD): Suatu Pengungkapan Informasi tentang Corporate Social Responsibility (CSR). Laporan penelitian tidak dipublikasikan, Fakultas Ilmu Administrasi Univ. Brawijaya.

Peery, Jr. Newman S. 1995. Business, Government, $\mathcal{E}$ Society: Managing Competitiveness, Ethics, and Social Issues. New Jersey: Prentice Hall.

Post, James E., Lawrence, Anne T., and Weber, James. 2002 (10 th ed.). Business and Society: Corporate Strategy, Public Policy, Ethics, New York: McGraw-Hill Companies.

Rubenstein, D. 2004. Good Corporate Citizen: A Practical Guide. New Jersey: John Wiley \& Son, Inc.

Steiner, George A. and Steiner, John F. 2000 (6 $6^{\text {th }}$ ed.). Business, Government, and Society: A Managerial Perspective Text and Cases, New York: McGraw-Hill.

Weihrich, H. \& Koontz, H. 1993 (10 th ed.). Management: A Global Perspective. New York: McGraw-Hill. 